\title{
LABORATORY DIAGNOSIS AND CLINICAL SIGNS OF CANINE VISCERAL LEISHMANIASIS IN DOGS EXAMINED AT THE CENTER FOR ZOONOSIS CONTROL IN CAMPO GRANDE - MS, BRAZIL
}

\author{
Rodrigo Casquero Cunha' ${ }^{1}$, Renato Andreotti', Elaine Araujo e Silva², Elisângela \\ Pereira $^{3}$, Tayra Sato ${ }^{1}$, Vanete Thomaz-Soccol ${ }^{4}$ \\ 1 Embrapa Beef Cattle \\ 2 Center for Zoonosis Control in Campo Grande \\ 3 Universidade Federal do Mato Grosso do Sul \\ 4 Positive University \\ Correspondência: Renato Andreotti: andreott@cnpgc.embrapa.br
}

\begin{abstract}
Visceral leishmaniasis is a type of zoonosis caused by several Leishmania species endemic to tropical, subtropical, and Mediterranean climate regions. Dogs are the primary source of infection in urban areas and can be symptomatic or asymptomatic. This study focused on the observation of clinical signs of leishmaniasis in dogs in Campo Grande, Mato Grosso do Sul, Brazil. Samples from affected animals were analyzed using indirect fluorescent antibody (IFA) tests, an enzyme-linked immunosorbent assay (ELISA), and polymerase chain reaction (PCR) assays to determine the optimal diagnostic tool for use on animals that present clinical symptoms. A predominance of clinical symptoms affecting the integumentary system was observed, and splenomegaly and hepatomegaly were the most important pathological signs. Among the diagnostic tests, the greatest agreement was seen between ELISA and IFA, followed by ELISA and PCR, and finally IFA and PCR. PCR diagnostic results showed the greatest extent of correlation with clinical signs, followed by ELISA and then IFA. When choosing a diagnostic method, veterinarians should consider the clinical signs and health status of the patient.
\end{abstract}

Key Words: ELISA; PCR; IFA; RV1/RV2 primers, Visceral leishmaniasis

\section{DIAGNÓSTICO LABORATORIAL E SINAIS CLÍNICOS PARA LEISHMANIOSE VISCERAL CANINA EM CÃES EXAMINADOS NO CENTRO DE CONTROLE DE ZOONOSES DE CAMPO GRANDE - MS}

RESUMO: A Leishmaniose Visceral é uma zoonose causada por várias espécies de Leishmania, sendo endêmica em paises de áreas Tropicais, Subtropicais e do Mediterrâneo. O cão é a principal fonte de infecção em regiões urbanas, podendo também desenvolver a doença. Neste trabalho fezse a observação de sinais clínicos de cães da cidade de Campo Grande - MS, que foram posteriormente submetidos aos testes de RIFI, ELISA e PCR, objetivando avaliar qual deverá ser a técnica de diagnóstico a ser solicitada, quando o animal estiver apresentando determinados sinais clínicos. Pode-se observar um predomínio de sinais clínicos relacionados ao sistema tegumentar. Os sinais anatomopatológicos de maior importância foram a esplenomegalia e a hepatomegalia. Dentre os testes diagnósticos, houve maior concordância entre ELISA e RIFI, seguido por ELISA e PCR e, por fim, RIFI e PCR. Quanto à concordâncias com os sinais clínicos, o teste diagnóstico que apresentou maior correlação com cada um foi a PCR, logo depois o ELISA e, com menor correlação, apresentou-se a RIFI. Afirma-se que, o clínico veterinário, ao decidir por uma técnica de diagnóstico, deve considerar os sinais clínicos observados e o estado de saúde do paciente.

Palavras-chave: ELISA, PCR, IFA, iniciadores RV1/RV2, Leishmaniose Visceral 

at the Center for Zoonosis Control in Campo Grande - MS, Brazil

\section{INTRODUCTION}

Visceral leishmaniasis (VL) is a zoonotic disease caused by several Leishmania species (Ross, 1903), all of which belong to the subgenus Leishmania and the $L$. donovani and $L$. infantum complexes (Thomaz-Soccol et al., 1993). In the Americas and in Mediterranean regions, the species $L$. (L.) infantum is responsible for $\mathrm{VL}$, which may affect humans who come into contact with the parasite transmission vectors. In the case of human transmission, the disease becomes an anthropozoonosis (Badaró, 1983).

$\mathrm{VL}$ is endemic to several countries in tropical, subtropical, and Mediterranean climate regions, including India, Sudan, Bangladesh, Nepal, and Brazil, all of which have economically underdeveloped areas and socially impoverished populations. These countries account for approximately $90 \%$ of reported VL cases (Gontijo and Melo, 2004; Chappuis et al., 2007). Mammals, including humans and wild animals (e.g., foxes, skunks, and rodents), are susceptible to VL infection, and in urban areas, VL primarily affects dogs that are bitten by the female phlebotomine sand fly (Lutzomia longipalpis), which is the vector species (Brasil, 2006; Gontijo and Melo, 2004).

The first VL cases in Brazil were reported in 1934, and in 1936, Evandro Chagas described the first case in vivo. VL was recognized as endemic in 1953, with outbreaks most commonly occurring in Ceará, Bahia, Piauí, and Minas Gerais (Michalick, 2005; Genaro, 1993). However, the epidemiological profile of $\mathrm{VL}$ in Brazil has been changing over time. Initially, the incidence of the disease was associated with poverty as well as canine and human malnutrition in rural or wild areas, such as in the Northeast region of Brazil. Currently, in the Southeast and Midwest regions of
Brazil, the disease occurs in urban and peri-urban areas, which is indicative of the urbanization of the disease (Brasil, 2006; Nunes et al., 1988).

Although Campo Grande is a rapidly developing and expanding city, it nonetheless exhibits distinct rural features that facilitate the adaptation and subsequent urbanization of VL. For this reason, state and municipal health departments, particularly those with primary health care services and services for health care professionals responsible for educational programs, must actively search for and communicate with populations in high risk areas to reduce VL cases in humans and dogs (Borges et al., 2008).

Canine visceral leishmaniasis (CVL) is a chronic disease and can be either symptomatic or asymptomatic. Symptomatic dogs may display apathy, alopecia, hair opacification, progressive weight loss, keratoconjuctivitis, facial dermatitis, nail stretching, nose and ear sores, swelling, and paresis of the hind paws. Asymptomatic animals are diagnosed through seropositivity. Depending on the stage of the disease and the immunological status of the animal, infected dogs can become important sources of Leishmania transmission (Gontijo and Melo, 2004; Silva et al., 2005; Costa et al., 2007).

The diagnosis of CVL in dogs can be performed based on the animals' clinical characteristics and can be confirmed by direct and indirect laboratory methods (Bonates, 2003). Direct methods of diagnosis include the visualization of the etiological agent in aspiration biopsies of lymphoid organs. Indirect methods are based on DNA testing and antibody detection using serological tests (Thomé, 1999; Feitosa et al., 2000). Currently, the Ministry of Health recommends the use of two serological tests: an enzyme-linked immunoabsorbent assay (ELISA) and an indirect fluorescent antibody (IFA) 
assay. The IFA assay is the most commonly used routine diagnostic technique (Brasil, 2004).

The goals of this study were to classify the clinical symptoms of CVL and compare the diagnostic efficacy of the serological tests (IFA and ELISA) and a polymerase chain reaction (PCR) assay using peripheral blood samples from dogs examined at the Center for Zoonosis Control in Campo Grande, Mato Grosso do Sul, Brazil, from 2009 to 2010.

\section{MATERIAL AND METHODS}

\section{Animals}

This study was conducted using 200 dogs that were examined at the Center for Zoonosis Control (Centro de Controle de Zoonozes - CCZ) in the municipality of Campo Grande, Mato Grosso do Sul, Brazil. The animals' owners submitted them to the center as the result of an intense educational campaign in the municipality on the importance of controlling leishmaniasis in dogs. The animals were examined for clinical signs and were classified into three groups according to their symptoms: asymptomatic (dogs in which no alterations were identified during a physical examination or by microscopic examination performed during autopsy), oligo-symptomatic (dogs that presented with up to three clinical symptoms, as revealed by physical examination, or that had up to three compromised organs), and symptomatic (dogs with more than three clinical symptoms, as revealed by physical examination, or which had more than three compromised organs).

\section{Indirect Immunofluorescence Test}

The IFA method is the "gold standard" for human leishmaniasis diagnosis and is also used for the diagnosis of $C V L$ in veterinary medicine. Briefly, the IFA assay is based on the reaction of sera suspected of infection with parasites fixed on microscope slides. The readout is performed using a microscope equipped for the detection of ultraviolet excitation light. Sera are considered positive when the parasites show fluorescent staining around the periphery, with a cutoff titer of 1:40 (BioManguinhos/Fiocruz kit). The established standard titer range used here was $1: 40$ to $1: 80$.

Enzyme-Linked

Assay

The ELISA used for the diagnosis of CVL (Leishmania donovani complex) was developed by Avrameas et al. in 1992 and modified by Laurentino-Silva (Bio-Manguinhos/Fiocruz kit). The result is typically obtained via the visual observation of a color change without the need for absorbance measurements. In the tests performed here, a titration ranging from 1:40 to $1: 80$ was used.

\section{Polymerase Chain Reaction Assays}

PCR reproduces in vitro the natural process of DNA replication and can be repeated on a large scale. For the development of primers, this methodology requires, at a minimum, partial knowledge of the target DNA of a particular organism (Yang and Rothman, 2004).

Blood samples were collected at the CCZ from dogs with a clinical suspicion of CVL or that were determined to be seropositive by ELISA and IFA. For each sample, $100 \mu \mathrm{L}$ of blood and $900 \mu \mathrm{L}$ of DNAzol were placed in 1.5-mL microtubes. The tubes were mixed thoroughly by inversion and centrifuged at $10,000 \times \mathrm{g}$ for 10 minutes. The supernatant of each tube was transferred to a clean tube, $1 \mathrm{~mL}$ of pure ethanol was added, and the sample was centrifuged for 3 minutes at $4,000 \times \mathrm{g}$. The precipitate was washed with $75 \%$ ethanol, centrifuged at $13,000 \times \mathrm{g}$ for 5 minutes, allowed to dry, and redissolved in $50 \mu \mathrm{L}$ of water. The purity and concentration of the DNA were 

at the Center for Zoonosis Control in Campo Grande - MS, Brazil

determined by measuring the optical density using a spectrophotometer (NanoDrop ${ }^{\circledR}$ ND-1000 UV-Vis) and by agarose gel electrophoresis.

A temperature curve was used to determine the optimal annealing temperature for the primers for the standardization of the PCR. The positive control, strain $L$. chagasi (MHOM/BR/74/PP/75), was provided by the Leishmaniasis Research Laboratory at the René Rachou/Fiocruz Research Center (Belo Horizonte, Brazil). Ultrapure water was used instead of DNA as the negative control. The following primers were used: RV1CTTTTCTGGTCCCGCGGGTAGG and RV2- CACCTGGCCTATTTTACACCA. These primers were expected to generate a 145-bp product (Lachaud et al., 2002).

The initial PCR was performed at a final volume of $25 \mu \mathrm{L}$ containing $1 \mu \mathrm{L}$ of DNA (40-100 ng/ $\mu \mathrm{L}$ ), $1 \mathrm{x}$ buffer, 0.2 $\mathrm{mM}$ dNTPs, $1.5 \mathrm{mM} \mathrm{MgCl}_{2}, 0.16 \mathrm{pmol}$ of each primer RV1 and RV2, $2 \mathrm{U}$ Taq polymerase, and water up to the final volume. Samples were amplified using a Eppendorf Mastercycler ${ }^{\circledR}$ Personal with standard cycles. Verification of the 145bp DNA fragment was performed using $10 \mu \mathrm{L}$ of PCR product in a $4 \%$ agarose gel with tris-acetate-EDTA (TAE) pH 8.0. Gels were stained with ethidium bromide $(0.5 \mathrm{mg} / \mathrm{mL})$ and visualized using a UV transilluminator.

\section{Statistical Analyses}

The results of the diagnostic analyses and the clinical symptoms of the animals were tested for pair-wise agreement based on the frequency distribution of each test and each clinical symptom. The following criteria were used to conceptualize the results in terms of their agreement: values $\leq 40 \%$ were considered poor; 40.1 to $79.9 \%$ was regular; 80 to $89.9 \%$ was good; and $\geq 90 \%$ was considered excellent. The results obtained using the diagnostic techniques were analyzed using the
Kappa coefficient test. The $p$ values were calculated using the McNemar test to establish the significance $(p<0.05)$ of the Kappa test.

\section{RESULTS}

\section{Clinical symptoms and pathological changes}

This study identified 37 asymptomatic dogs, 62 oligosymptomatic dogs, and 101 symptomatic dogs. The primary symptoms were weight loss $(40 \%)$, onychogryphosis (39\%), pinna dermatitis $(31 \%)$, and lymphadenopathy $(29.0 \%)$. Less common symptoms were splenomegaly (18\%), conjunctivitis $(17.5 \%)$, peeling (15.5\%), skin laceration $(12 \%)$, myotrophies $(11.5 \%)$, alopecia $(11.5 \%)$, and dermatitis (10\%). Other clinical symptoms occurred in less than $10 \%$ of the animals (Figure 1 ).

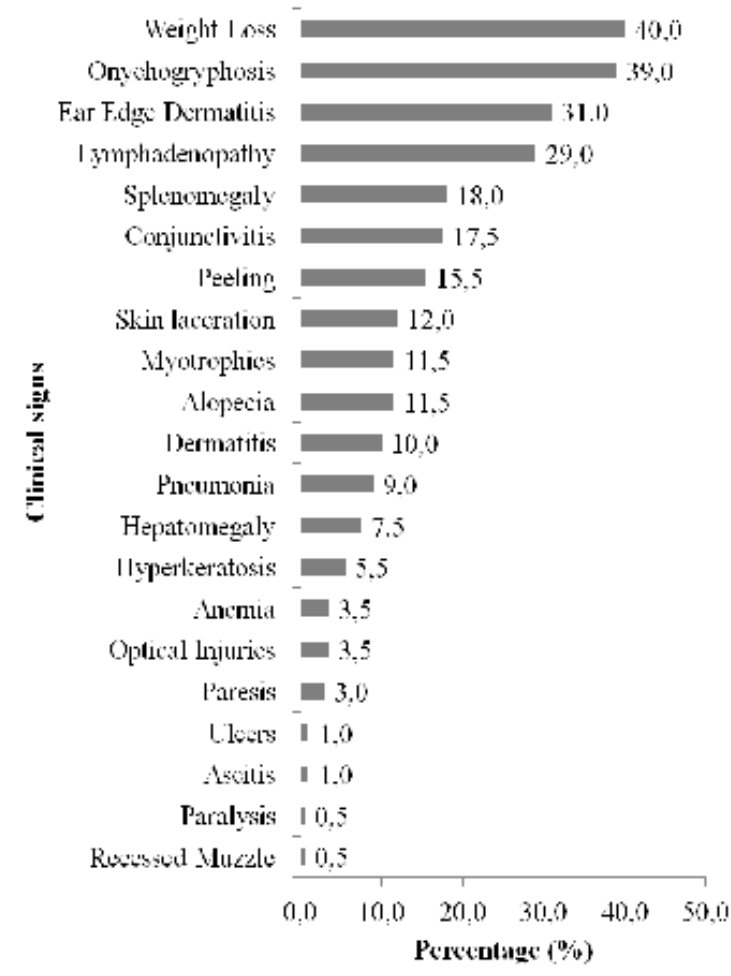

Figu re 1- Clinical symptoms observed in 200 dogs with canine visceral leishmaniasis in Campo Grande, MS, Brazil, in 2009. 


\section{Diagnostic tests}

IFA assays identified 160 dogs $(80 \%)$ that were positive for leishmaniasis, whereas 130 (65\%) and 95 (47.5\%) cases were identified using ELISA and PCR, respectively. According to all three diagnostic tests, 65 animals were positive (32.5\%) and 25 were negative (12.5\%).

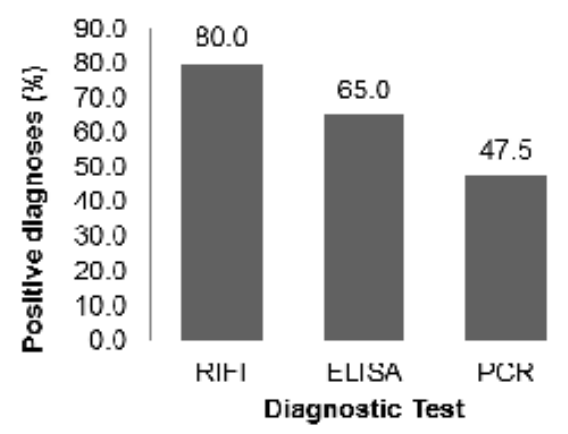

Figu re 2- Percentage of dogs positive for CVL according to serological tests (IFA and ELISA) and PCR.

The comparison of IFA, ELISA, and PCR diagnostic test results, including the percent agreement percentages, Kappa coefficients, and $p$ values, are shown in Table 1.

Table 1 - Analysis of the agreement between IFA, ELISA and PCR results.

\begin{tabular}{llll}
\hline \multirow{2}{*}{ Statistics } & \multicolumn{3}{c}{ Diagnostic Tests } \\
\cline { 2 - 4 } & IFA x EUSA & IFA x PCR & EUSA x PCR \\
\hline Agreement & $83 \%$ & $53.50 \%$ & $54.80 \%$ \\
Kappa & 0.58 & 0.097 & 0.093 \\
p Value & $<0.0001^{1}$ & $<0.0001^{1}$ & 0.7 \\
\hline $1-p<0.05$ & & &
\end{tabular}

Diagnostic results compared to clinical symptoms

The group of asymptomatic dogs had the lowest number of animals (37) and the least number of positive results according to all three tests: 29 (14.5\%) cases by IFA, 26 (13\%) by ELISA, and $17(8.5 \%)$ by PCR. Among the group of 62 oligo-symptomatic dogs, 57 (28.5\%) were diagnosed by IFA, $47(23.5 \%)$ by ELISA, and 31 (15.5\%) by PCR. The largest number of positive results (101 animals) was observed for the symptomatic group, of which 74 (37\%) were seropositive by IFA, 57 (28.5\%) were identified by ELISA, and 47 $(23.5 \%)$ were indicated by PCR. This group also had the highest percentage of positive diagnoses of CVL.

The frequency of positive results for each diagnostic test among the asymptomatic, oligo-symptomatic, and symptomatic groups is shown in Table 2. Table 2 - Frequency of positive diagnoses for CVL distributed
among the symptomatic, oligo-symptomatic, and symptomatic groups for a total of 200 animals.

\begin{tabular}{lccc}
\hline \multirow{2}{*}{ Clinical State } & \multicolumn{3}{c}{ Diagnostic test } \\
\cline { 2 - 4 } & IFAN(\%) & ELISA N(\%) & PCR N(\%) \\
\hline Asymptomatic $(n=37)$ & $29(14.5)$ & $26(13)$ & $17(8.5)$ \\
Oligo-symptomatic $(n=62)$ & $57(28.5)$ & $47(23.5)$ & $31(15.5)$ \\
Symptomatic $(n=101)$ & $74(37)$ & $57(28.5)$ & $47(23.5)$ \\
\hline Total $(n=200)$ & $160(80)$ & $130(65)$ & $95(47.5)$ \\
\hline \multicolumn{1}{c}{$\mathrm{N}=$ number of pos itive animalia diagnosed } &
\end{tabular}

\section{Asymptomatic Dogs}

Table 3 shows the comparative data for the diagnostic tests (IFA, ELISA, and PCR) performed using the peripheral blood of asymptomatic dogs; the percent agreement, Kappa coefficient and $p$ value results are reported. In this group, 13 (35\%) of the animals were positive, and 5 (13.5\%) were negative in all three diagnostic tests performed. Of the remaining animals, only a single type of test indicated a positive result in a total of 5 cases: 3 were positive only by IFA, 1 was only positive according to ELISA, and 1 was identified by PCR alone. Similarly, 1 animal was negative only according to IFA, whereas 2 and 11 cases were negative only according to ELISA and PCR results, respectively. The agreement within this group was $48.5 \%$ among the three tests.

Table 3 - Results for IFA, EUSA and PCR tests performed on the

\begin{tabular}{lccc} 
& \multicolumn{3}{c}{ asymptomatic group of animals } \\
\cline { 2 - 4 } Statistics & IFA x ELISA & IFA x PCR & EUSA x PCR \\
\hline Agreement & $81.08 \%$ & $56.76 \%$ & $59.46 \%$ \\
Kappa & 0.5085 & 0.1732 & 0.2150 \\
p Value & 0.2568 & $0.0027^{1}$ & $0.0201^{1}$ \\
\hline $1-p<0.05$ & \multicolumn{3}{c}{}
\end{tabular}

\section{Oligo-symptomatic dogs}

The comparison of IFA, ELISA, and PCR test results obtained using the peripheral blood of oligo-symptomatic dogs is presented in Table 4, which includes the percent agreement, Kappa 

at the Center for Zoonosis Control in Campo Grande - MS, Brazil

coefficient, and $\mathrm{p}$ value results. In this group, 24 (38.7\%) dogs were positive and $4(6.4 \%)$ were negative according to the IFA, ELISA, and PCR tests. In addition, 4 animals were positive only by ELISA, and 1 was positive by PCR only; 6 were negative by ELISA only, and 23 were negative according to PCR only. In this group, the agreement among the three diagnostic tests was $45.1 \%$.

\begin{tabular}{|c|c|c|c|}
\hline \multirow{2}{*}{ Statistics } & \multicolumn{3}{|c|}{ Diagnostic tests } \\
\hline & IFA x EUSA & IFA x PCR & EUSA x PCR \\
\hline$\overline{\text { Agreement }}$ & $83.87 \%$ & $54.84 \%$ & $51.61 \%$ \\
\hline Kappa & 0.4312 & 0.0968 & 0.0323 \\
\hline pvalue & $0.0016^{1}$ & $<0.0001^{1}$ & $0.0035^{1}$ \\
\hline
\end{tabular}

\section{Symptomatic dogs}

The data comparing the results of the IFA, ELISA, and PCR diagnostic tests using peripheral blood collected from symptomatic dogs are shown in Table 4, including the percent agreement, kappa coefficient, and $p$ value results. In this group, 28 (27.7\%) of the animals were positive and 16 $(15.8 \%)$ were negative for all three diagnostic tests. A total of 9 animals were positive only by IFA and 11 were positive only by PCR; 8 animals were negative only by ELISA and 29 were negative only by PCR. This group showed $43.5 \%$ agreement among the three diagnostic tests.

Table 5 - Results of the IFA, ELISA, and PCR tests performed
on the symptomatic animal group compared
using the Kappa test.

\section{Diagnostic test results compared to clinical manifestations}

The clinical symptoms most commonly observed during the clinical examinations of the animals are shown in Table 6. In this table, each clinical symptom is correlated with each of the three diagnostic tests in a pair-wise comparison. The percent agreement between each clinical symptom and the respective diagnostic test was calculated to determine the most accurate diagnostic test to be used when a clinical symptom is presented. The Kappa test indicates the magnitude of this correlation, and the $p$ value indicates the significance of the Kappa test.

\begin{tabular}{|c|c|c|c|c|}
\hline \multirow[b]{2}{*}{ SYMPTOMS } & & \multicolumn{3}{|c|}{ DIAGNOSTIC METHOD } \\
\hline & & PCR & IF A & ELISA \\
\hline & Agreement & $55 \%$ & $29.5 \%$ & $41.5 \%$ \\
\hline \multirow[t]{3}{*}{ Alopecia } & Kappa & 0.064 & 0.036 & 0.050 \\
\hline & p value & $<0.0001$ & $<0.0001$ & $<0.0001$ \\
\hline & Agreement & $50 \%$ & $27.5 \%$ & $34.5 \%$ \\
\hline \multirow[t]{3}{*}{ Conjunctivitis } & Kappa & 0.034 & 0.043 & 0.047 \\
\hline & $\mathrm{p}$ value & $<0.0001$ & $<0.0001$ & $<0.0001$ \\
\hline & Agreement & $52.5 \%$ & $26 \%$ & $38 \%$ \\
\hline \multirow[t]{3}{*}{ Dermatitis } & Kappa & 0.010 & 0.000 & 0.000 \\
\hline & pvalue & $<0.0001$ & $<0.0001$ & $<0.0001$ \\
\hline & Agreement & $51.5 \%$ & $47 \%$ & $51 \%$ \\
\hline \multirow[t]{3}{*}{ Pinna Dermatitis } & Kappa & 0.011 & 0.137 & 0.120 \\
\hline & $\mathrm{p}$ value & $<0.0001$ & $<0.0001$ & $<0.0001$ \\
\hline & Agreement & $56 \%$ & $33.5 \%$ & $44.5 \%$ \\
\hline \multirow[t]{3}{*}{ Peeling } & Kappa & 0.089 & 0.059 & 0.080 \\
\hline & $\mathrm{p}$ value & $<0.0001$ & $<0.0001$ & $<0.0001$ \\
\hline & Agreement & $51.5 \%$ & $41 \%$ & $38 \%$ \\
\hline \multirow[t]{3}{*}{ Weight loss } & Kappa & 0.089 & 0.059 & 0.080 \\
\hline & pvalue & $<0.0001$ & $<0.0001$ & $<0.0001$ \\
\hline & Agreement & $48.5 \%$ & $33 \%$ & $44 \%$ \\
\hline \multirow[t]{3}{*}{ Splenomegaly } & Kappa & 0.064 & 0.031 & 0.060 \\
\hline & $p$ value & $<0.0001$ & $<0.0001$ & $<0.0001$ \\
\hline & Agreement & $45 \%$ & $45.5 \%$ & $54.5 \%$ \\
\hline \multirow[t]{3}{*}{ Lymphadenopathy } & Kappa & 0.124 & 0.134 & 0.194 \\
\hline & p value & 0.0003 & $<0.0001$ & $<0.0001$ \\
\hline & Agreement & $49.5 \%$ & $46 \%$ & $49 \%$ \\
\hline \multirow[t]{2}{*}{ Onychogryphosis } & Kappa & 0.021 & 0.046 & 0.043 \\
\hline & p value & $0.091^{1}$ & $<0.0001$ & $<0.0001$ \\
\hline
\end{tabular}

$1-p>0.05$

\section{DISCUSSION}

A predominance of clinical symptoms related to the integumentary system was observed, and 127 of 200 $(63.5 \%)$ animals presented symptoms related to this system. Considering only those animals that showed clinical symptoms (163), the presence of clinical symptoms associated with the 
integumentary system was observed in 127 of 163 (78\%) animals, which was a highly significant occurrence. Of these, 59 of 127 (46.5\%) presented 1 clinical symptom, 42 of 127 (33.1\%) presented 2 clinical symptoms, 21 of 127 (16.5\%) had 3 clinical symptoms, and 5 of 127 (4\%) had more than 3 clinical symptoms associated with the integumentary system. Thus, the observation of these symptoms by the veterinarian is of paramount importance in cases of suspicion of CVL and these symptoms are important for the differential diagnosis of demodicosis.

The most important pathological symptoms were splenomegaly and hepatomegaly, which were present in 36 $(18 \%)$ and $15(7.5 \%)$ of the 200 studied dogs, respectively. Of all the animals that showed hepatomegaly, only one did not present concurrent splenomegaly. Therefore, we believe that hepatomegaly occurs after splenomegaly and depends on disease progression.

Other commonly presented clinical symptoms were presented: weight loss in 80 of 200 (40\%) dogs; lymphadenopathy in 58 of 200 (29.0\%) dogs; and conjunctivitis in 35 of 200 $(17.5 \%)$ of dogs. Other clinical symptoms were not as common. The great variability of clinical manifestations of CVL may be due to the genetic characteristics of each dog, which also determine the different immune responses seen in these animals. Additionally, some animals or breeds can be more resistant than others, thereby determining the disease susceptibility (Solano-Gallego et al., 2000).

In the diagnostic assays, 90 of 200 dogs were positive for all three diagnostic tests with $45 \%$ agreement among the tests. According to the Kappa tests for the pairwise comparisons, there was a greater agreement between
ELISA and IFA, followed by ELISA and PCR, and finally IFA and PCR.

Using only the ELISA diagnostic test, 130 (65\%) samples were positive for CVL. When combined, ELISA and IFA increased the positive sample detection rate by $16 \%$ (32 of 200) for a total of $81 \%$ (162 of 200 ). If the PCR results were included, there was a $12.5 \%$ increase (25 of 200 ) for a total detection rate of $93.5 \%$ (187 of 200 ) of the CVL-positive samples. Therefore, the use of two or more techniques is recommended for the epidemiological control of canine leishmaniasis.

The symptomatic dog group, with a total of 101 animals (50.5\%), comprised the largest group identified in this study. All three tests proved to be effective for this group. Accordingly, the symptomatic group showed the highest positive rate in the diagnostic tests, followed by the oligo-symptomatic and asymptomatic groups. Independent of the clinical group, IFA showed the highest positive rate for the diagnosis of CVL, followed by ELISA, and then PCR. The better performance of serological tests for diagnosing CVL can be explained by the high polyclonal stimulation of $B$ lymphocytes caused by leishmaniasis, which leads to hypergammaglobulinemia and the extensive production of antibodies that facilitate diagnosis by these tests (Feitosa et al., 2000).

ELISA is a relatively quick and simple test but requires trained personnel and specialized, expensive equipment. This test is sensitive; i.e., it allows for the detection of low titers of antibodies with a sensitivity of greater than 98\% (Rey, 2001, Thomaz-Soccol et al., 2009). IFA is now considered the test of choice by the Brazilian Ministry of Health in canine sero-surveys and exhibits $90 \%$ to $100 \%$ sensitivity and a specificity of approximately $80 \%$ in sera samples. Additionally, ELISA is a relatively easy test to perform with fast 

at the Center for Zoonosis Control in Campo Grande - MS, Brazil

results and a low cost (Alves and Bevilacqua, 2004). However, there has been disagreement in the literature regarding the need for two or more diagnostic methods to increase rate of correct diagnosis of leishmaniasis (Szargiki et al., 2009).

When compared to clinical symptoms, the PCR-based diagnostic test showed the greatest correlation, with $45 \%$ to $55 \%$ agreement with each clinical symptom, followed by ELISA, with $34.5 \%$ to $54.5 \%$ agreement. The lowest correlation was observed for IFA with $26 \%$ to $47 \%$ agreement with each clinical symptom. In other words, the test with the highest positive result rate, IFA, was the method with the lowest extent of correlation with clinical signs. In contrast, the test with the lowest positive rate, PCR, had the highest correlation with clinical signs. However, it is known that low levels of parasitemia in infected animals can contribute to low detection rates by $\mathrm{PCR}$ in blood samples, as reported by Fisa et al. (2001). The PCR technique could be improved if samples were collected from the popliteal lymph node or the leukocyte layer because these would house greater numbers of parasites, thereby increasing the sensitivity of detection.

The correlation results of the tests used in this study support those of other recent studies, such a report by as Lachoud et al. (2002), who motivated Gomes et al. (2007) to conduct a study to verify the ability of PCR (RV1/RV2) to diagnose $C V L$ in different tissue samples from dogs in the State of São Paulo, Brazil. In another study conducted with 95 dogs in Italy, Manna et al. (2004) reported a 94\% positive rate using PCR, with 4 animals positive by PCR that were negative according to other serological tests. In this present study, 13 of $200(6.5 \%)$ animals were positive by PCR and negative by other diagnostic tests.
In this study, PCR proved to be the safest and most cost-effective test relative to the serological tests (IFA and ELISA), which have been shown to have several disadvantages, including the difficulty in differentiating between current and previous parasitic infections. Additionally, it is not possible to correlate the levels of circulating antibodies with the disease stage using IFA and ELISA, and the cost of producing specific purified antigens can be prohibitively high. Consequently, preparations with crude antigens are often used, thereby reducing the specificity and sensitivity of these tests (Green, 2006) and generating a relatively high false positive rate.

In veterinary medicine, the clinician is often confronted with cases suggestive of certain canine diseases, although diagnostic tests can indicate contradictory results (Francino et al., 2006). In this study, PCR showed the lowest percentage of contradictory results when compared with observed clinical signs. Therefore, this article can serve as a tool to help veterinary doctors select a diagnostic technique while taking into account the observed symptoms and the patient status.

\section{CONCLUSION}

In this study, we used a relatively large number of dogs (200) for the clinical and laboratory evaluation of CVL. The objective of classifying dogs using clinical symptoms and the comparison of IFA, ELISA, and PCR tests was achieved. However, even with this representative sample number, the results support previous findings that demonstrate that no one diagnostic test is capable of properly identifying dogs with CVL when used alone. Although PCR showed the greatest correlation with the presence of clinical symptoms, our results clearly demonstrated that a 
negative result based on a single type of test can be misleading and may instead represent a false negative result. These results stress the need to employ a combination of diagnostic techniques. However, when a strong clinical suspicion is present, our results show that PCR is essential for reaching a definitive diagnosis. Finally, veterinarians should always consider the clinical symptoms and health status of the patient when selecting a diagnostic test.

\section{ACKNOWLEDGEMENTS}

We thank CNPq and Fundect/MS for their financial support.

\section{REFERENCES}

ALVES, W.A.; BEVILACQUA, P.D. Reflections on the quality of diagnosis of canine visceral leishmaniasis in epidemiological surveys: the case of the epidemic in Belo Horizonte, Minas Gerais, Brazil, 1993-1997. Cadernos de Saúde Pública, v.20, n.1, p.259-265, 2004.

BADARÓ, R.; REED, S.G.; CARVALHO, E.M. Immunofluorescent antibody test in American visceral leishmaniasis: sensitivity and specificity of different morphological forms of two Leishmania species. The American Journal of Tropical Medicine and Hygiene, v.32, n.3, p.480-84, 1983.

BRASIL. Health Surveillance Secretariat. Manual for Surveillance and Control of Visceral Leishmaniasis. Brasília, DF: Ministry of Health, 2004, 120p.

BRASIL. Ministry of Health. Manual for the surveillance and control of American Visceral Leishmaniasis in the state of São Paulo. Série A. Standards and Technical Manuals. Brasília: Ministry of Health. 2006, 160p.

BONATES, A. Visceral Leishmaniasis (calazar). Vet News, Rio de Janeiro, v.10, n.61, p.4-5, 2003.

BORGES, B.K.A.; SILVA, J.A.; HADDAD, J.P.A. et al. Evaluation of the level of knowledge and attitudes of the population on preventive visceral leishmaniasis in Belo Horizonte, Minas Gerais,
Brazil. Cadernos de Saúde Pública, v.24, n.4, 2008.

CHAPPUIS, F.; SUNDAR, S.; HAILU, A. et al. Visceral Leishmaniasis: what are the needs for diagnosis, treatment and control? Nature

Reviews, v.5, n.11, p.873-82, 2007.

COSTA, C.H.N.; TAPETY, C.M.M.; WERNECK, G.L. Control of visceral leishmaniasis in urban areas: randomized factorial study. Revista da Sociedade Brasileira de Medicina Tropical, v.40, n.4, p.415-419, 2007.

FEITOSA, M.M.; IKEDA, F.A.; LUVIZOTTO, M.C.R. et al. Clinical features of dogs with visceral leishmaniasis in the municipality of Araçatuba - São Paulo (Brazil). Clínica Veterinária, v.5, n.28, p.36-44, 2000.

FISA, R.; RIEIRA, C.; GÁLLEGO, M. et al. Nested PCR for diagnosis of canine leishmaniasis in peripheral blood, lymph node and bone marrow aspirates. Veterinary Parasitology, v.99, n.2, p.105-111, 2001.

FRANCINO, O.; ALTET, L.; SÁNCHEZROBERT, E. et al. Advantages of real-time PCR assay for diagnosis and monitoring of canine leishmaniasis. Veterinary Parasitology, v.137, n.3-4, p.214-221, 2006.

GENARO, O. Experimental canine visceral leishmaniasis. 1993. Belo Horizonte. 202 f. Tese (Doutorado em Parasitologia) - Curso de pós-graduação em Parasitologia, Universidade Federal de Minas Gerais.

GREENE, C.E. Infections Diseases of the dog and cat. 3.ed. Philadelphia: W.B. Saunders, 2006. 1440p.

GOMES, A.H.S.; FERREIRA, I.M.R.; LIMA, M.L.S.R. et al. PCR identification of Leishmania in diagnosis and control of canine leishmaniasis. Veterinary Parasitology, v.144, n.3-4, p.234241, 2007.

GONTIJO, C.M.F.; MELO, M.N. Visceral leishmaniasis in Brazil: current situation, challenges and prospects. Revista Brasileira de Epidemiologia, v.7, n.3, p.338-349, 2004.

LACHAUD, L.; CHABBERT, E.; DUBESSAY, P. et al. Value of two PCR methods for the diagnosis of canine visceral leishmaniasis and the detection of asymptomatic carriers.

Parasitology, v.125, n.3, p.197-207, 2002. 
MANNA, L.; VITALE, F.; REALE, S. et al.

Comparison of different tissue sampling for PCR based diagnosis and follow-up of canine visceral leishmaniasis. Veterinary Parasitology, v.125, n.3-4, p.251-262, 2004.

MICHALIK, M.S.M. The genus Leishmania. In: NEVES D P Parasitologia humana. 11.ed. São Paulo: Atheneu, 2005, p. 41-46.

NUNES, V.L.B.; YAMAMOTO, Y.Y.; REGO, Jr. F.A. et al. Epidemiological aspects of Visceral Leishmaniasis in Dogs in Corumbá - Mato Grosso do Sul. Pesquisa Veterinária

Brasileira, v.8. n.1-2, p.17-21, 1988.

REY, L. () Parasites and parasitic diseases of man in the Americas and Africa. In:

Parasitologia. 3.ed. Rio de Janeiro: Guanabara Kooganp, 2001. p.856.

ROSS, R. Note on the bodies recently described by Leishman-Donovan and further notes on Leishman's bodies. British Medical Journal, v.2, p.1261-1401, 1903.

SILVA, A.V.M.; DE PAULA, A.A.; CABRERA, M.A.A. et al. Leishmaniasis in domestic dogs: epidemiological aspects. Caderno de Saúde Pública, v.21, n.1, p.324-328, 2005.

SZARGIKI, R.; CASTRO, E.A.; LUZ, E. et al. Comparison of serological and parasitological methods for cutaneous leishmaniasis diagnosis in the state of Parana, Brazil. Brazilian Journal of Infectious Diseases, v.13, n.1, p.47-52, 2009.

SOLANO-GALLEGO, L.; LLULL, J.; RAMOS, G. et al. The Ibizian hound presents a predominantly cellular immune response against natural Leishmania infection. Veterinary

Parasitology, v.90, n.1-2, p.37-45, 2000.

THOMAZ-SOCCOL, V.; LANOTTE, G.; RIOUX, J.A. et al. Monophyletic origin of the genus Leishmania Ross,1903. Annales de Parasitologie Humaine et Comparee, v.68, n.2, p.107-108, 1993.

THOMAZ-SOCCOL, V.; CASTRO, A.E.; NAVARRO, I.T. et al. Allochthonous cases of canine visceral leishmaniasis in Paraná, Brazil: epidemiological implications. Revista Brasileira de Parasitologia, v. 8, n.3, p.46-51, 2009. 